\title{
Stèle pour Claude Simon
}

\section{Michel Butor}

\section{(2) OpenEdition}

\section{Journals}

Édition électronique

URL : http://journals.openedition.org/ccs/474

DOI : $10.4000 /$ ccs. 474

ISSN : 2558-782X

\section{Éditeur :}

Presses universitaires de Rennes, Association des lecteurs de Claude Simon

\section{Édition imprimée}

Date de publication : 31 décembre 2006

Pagination : 61-62

ISBN : 9782914518895

ISSN : 1774-9425

\section{Référence électronique}

Michel Butor, «Stèle pour Claude Simon », Cahiers Claude Simon [En ligne], 2 | 2006, mis en ligne le 20 septembre 2017, consulté le 14 septembre 2020. URL : http://journals.openedition.org/ccs/474 


\section{Stèle pour Claude Simon par Michel BUTOR}

Une enfance dans les vignes auprès d'une forteresse de l'autre côté des monts le vacarme de la guerre on veut y participer ce n'est que pour assister à l'écrasement du droit

Mais c'est loin d'être fini reprend la guerre la guerre ici et là un brandon qui rallume en incendie les souvenirs d'autres guerres celles du début du siècle celles des siècles passés

Les vieilles femmes en parlent tandis que les rescapés s'efforcent d'exorciser les images effroyables qui reviennent les hanter cherchent à cicatriser les débâcles successives 
Si la prochaine s'annonce que faire pour l'éviter sinon raconter encore le plus calmement possible en prenant de la distance dans l'effilochement cru du temps qui ne passe pas

Donc éditions promotions interviews de journalistes cela n'a pas d'importance les prix tombent comme ils peuvent on n'aura rien fait pour ça on fera bonne figure ou du moins on essaiera

Mais on est bien loin du compte et le saignement des phrases se coagule en romans pour élever taciturne les livres s'accumulant une stèle solitaire sur l'étendue des gravats 